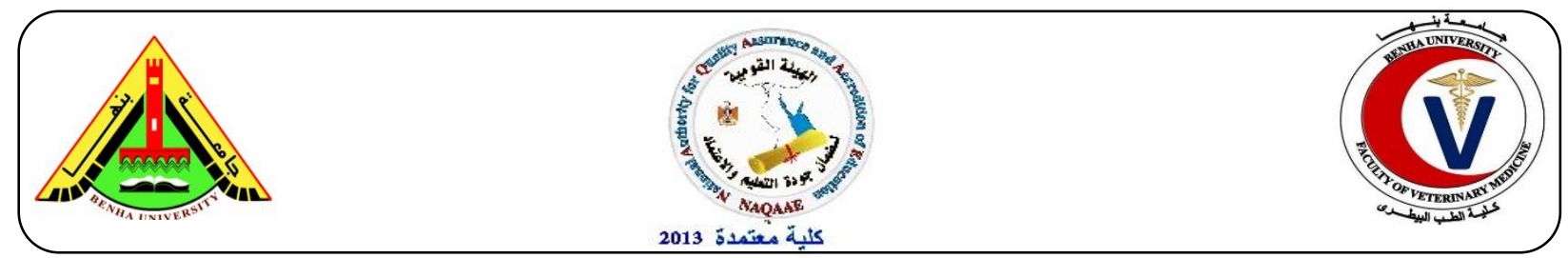

\title{
Prevalence and molecular studies on Listeria monocytogenes isolated from chicken in El-Gharbia Governorate
}

\author{
Ashraf A. Abd El-Tawab ${ }^{1}$; Seham N. Homouda ${ }^{2}$; Shimaa E. El-Haw ${ }^{3}$ \\ ${ }^{I}$ Department of Bacteriology, Immunology and Mycology, Faculty of Veterinary Medicine, Benha University, \\ 13736 Moshtoher, Benha, Egypt; ${ }^{2}$ Animal Health Research Institute "Tanta branch"; ${ }^{3}$ Veterinarian.
}

\section{A B S T R A C T}

Listeria monocytogenes is the causative agent of listeriosis and food-borne disease that can lead to meningitis and bacteremia. L. monocytogenes is the most pathogenic species in the genus Listeria. A total of 400 random samples of muscles, liver, spleen and kidneys (100 samples each) were taken from 100 diseased chickens. All samples were obtained from different poultry farms and markets in ElGharbia Governorate to estimate the prevalence of Listeria monocytogenes in chicken. The bacteriological examination of the samples resulted; 53(13.25\%) isolates as 11, 21, 8 and 13 from muscles, liver, spleen and kidneys respectively. The antimicrobial sensitivity test showed that the isolated L. monocytogenes were sensitive to sulfamethoxate-trimethoprim (91.6\%) followed by ampicillin, gentamycin, vancomycin and chloromphenicol $(83.3 \%)$ followed by ciprofloxacin $(66.6 \%)$ followed by erythromycin and tetracycline $(50.0 \%)$, while the isolated strains were completely resistant to cephalothin. All L. monocytogenes strains were virulent where all of them were positive to CAMP test and Anton's test. The PCR results for six studied strains of isolated L. monocytogenes showed that all genes (16S rRNA; inlA; prfA and hlyA) were detected (100.0\%) while plcA gene was not detected.

Keywords: Listeria monocytogenes, chicken, PCR, virulence genes.

(BVMJ, 34 (1), 2018)

\section{INTRODUCTION}

Listeria monocytogenes is the causative agent of listeriosis, a food-borne disease that can lead to meningitis and bacteremia (Mackiw et al., 2016).

Listeria spp. are considered as an important cause of zoonoses infecting many types of animals such as domestic pets, avian species, rodents, livestock, fish, amphibians and arthropods. The approximate fatality rate is $30 \%$ that may increase up to $75 \%$ in high risk groups, such as neonates, pregnant women and immunecompromised adults (Jalali and Abedi, 2007).

The genus Listerias presently composed of 17 different species: $L$. monocytogenes, L. seeligeri, L. ivanovii, $L$. welshimeri, L. marthii, L. innocua, L. grayi, L. fleischmannii, L. floridensis, L. aquatica, $L$. newyorkensis, $L$. cornellensis, $L$. rocourtiae, L. weihenstephanensis, $L$. 
grandensis, L. riparia and L. booriae (Orsi and Wiedmann, 2016).

Morphologically, L. monocytogenes is a gram-positive small, ranging from 1 to 2 $\mu \mathrm{m}$ in length and $0.5 \mu \mathrm{m}$ in diameter, rodlike shape bacteria with rounded ends. Cells are usually in single units but can be clustered in short chains (3-5 or more) arranged in a $\mathrm{V}$ or $\mathrm{Y}$ disposition as well as in palisades. It is considered motile showing tumbling motility due to the production of peritrichous flagella when grown below 30 ${ }^{\circ} \mathrm{C}$, due to flagellin being produced and assembled in flagella at cell surface. If grown at $37{ }^{\circ} \mathrm{C}$, flagellin production is reduced to residual (Ryser and Marth, 2007).

L. monocytogenes are classified into13 different serotypes based on somatic $(\mathrm{O})$ and flagellar $(\mathrm{H})$ antigens. 1/2a, 1/2b, $1 / 2 c$, and $4 b$ are the four main pathogenic serotypes from which $1 / 2 \mathrm{a}, 1 / 2 \mathrm{~b}$ and $4 \mathrm{~b}$ are responsible for $98 \%$ of human Listeriosis (Jacquet et al., 2002).

L. monocytogenes usually shed in all the secretions and excretions of the infected birds. Disease is transmitted through ingestion of contaminated feed, water, litter and soil. Infection can also follow inhalation or wound contamination. In birds, generally, the infection is subclinical and incubation period is not reported (Kurazono et al., 2003).

Signs of Listeriosis infection in birds, if seen, are suggestive of septicemia and may include depression and listlessness, emaciation, diarrhea and per acute/sudden death can occur at times (Akanbi et al., 2008).
Listeria is sensitive to a wide range of antibiotics: ampicillin, amoxicillin, tetracycline, chloramphenicol, -lactam antibiotics together with an aminoglycoside, trimethoprim and sulphamethoxazole are recommended (Altuntas et al., 2012).

Further identification of the pathogenic $L$. monocytogenes a set of genes are responsible for the virulence activity of $L$. monocytogenes must be detected (Shen et al., 2013). The virulence genes of $L$. monocytogenes are inlA, inlB, hlyA, prfA, $p l c A, p l c B, m p l$ and actA (Karthikeyan et al., 2015). inlA is a gene that responsible for the survival and invasion of $L$. monocytogenes of intestinal epithelium (Liu et al. 2007) While inlB responsible for hepatocyte colonization (Kirkan et al., 2005) and the well-recognized virulence gene is $h l y A$ which encodes the Listeriolysin O (Gouws and liedemann 2005) and finally the regulatory gene for those virulent genes prfA which encodes the promoter protein for inlA, inlB and hlyA (Scortti et al., 2007).

\section{MATERIAL AND METHODS}

\subsection{Collection of the samples:}

A total of 400 random samples of muscles, liver, spleen and kidneys (100 samples each) were taken from100 diseased chickens during November 2016 to April 2017. All samples were obtained from different poultry farms and markets in ElGharbia Governorate. The examined samples were collected separately under hygienic measure as possible and transferred directly in ice box to the laboratory (Animal health research laboratory in Tanta) for bacteriological examination. 
Prevalence and molecular studies on Listeria monocytogenes isolated from chicken in El-Gharbia Governorate

\subsection{Bacteriological examination:}

Listeria monocytogenes was isolated from the examined samples according to 11290-1:1996/Amd.1:2004 (ISO, 2005).

Approximately 25 grams of samples were added to $225 \mathrm{ml}$ half-Fraser broth (Oxoid) in a 500ml flask and mixed well by shaking. The enrichment broth was incubated at $30^{\circ} \mathrm{C}$ for 24 hours. Then, $1 \mathrm{ml}$ from the half-Fraser broth was transferred into $9 \mathrm{ml}$ of Fraser broth (Oxoid) and incubated at $37^{\circ} \mathrm{C}$ for 48 hours.

Loopful of incubated Fraser broth was streaked onto PALCAM agar media then the plates were incubated at $37 \pm 1^{\circ} \mathrm{C}$ for 48 hours and examined after $24 \pm 3$ hours and the positive one was further streaked onto Oxford agar and ALOA agar plates then the plates were incubated at $37 \pm 1^{\circ} \mathrm{C}$ for 48 hours and examined after $24 \pm 3$ hours. The Listeria like colonies were picked and streaked onto Tryptic Soy agar with $0.6 \%$ yeast extract (TSA,YA) then, incubated at $35^{\circ} \mathrm{C}$ for 48 hours, the isolates were morphologically identified by Gram' stain according to Quinn et al., (2011) and biochemical tests (Catalase reaction, Oxidase test, Nitrate reduction test, Urease test, Methyl red test (MR), Vages-proskauer test (VP), Carbohydrate fermentation test, Esculin test Gelatin hydrolysis test and Motility tests) were applied according to Markey et al., (2013).

\subsection{Virulence tests:}

\subsubsection{Hemolytic activity:}

All isolates were cultured onto 5\% sheep blood agar to determine their hemolytic activity. In addition to, they were subjected to CAMP test (Christie-AtkinsMunoh-Peterson), (McKellar, 1994) by streaking of Staphylococcus aureus strains in single straight lines in parallel on sheep blood agar plates, the isolated listeria strains streaked perpendicularly, with quite touching (1-2mm). After incubation for 2448 hours at $35^{\circ} \mathrm{C}$, a positive reaction consists of an enhanced zone of $\beta$ hemolysis.

\subsubsection{The biological characters:}

Anton's test (Quinn et al., 2002) by instillation 2-3 drops of listeria suspension into the conjunctiva of rabbits.

\subsection{In-Vitro anti-microbial sensitivity test (CLSI, 2014):}

All L. monocytogenes isolates were tested for their antimicrobial resistance/susceptibility pattern by disc diffusion technique according to (CLSI, 2014). By using antimicrobial discs as fluoroquinolones represented by ciprofloxacin; $\beta$-lactam represented by ampicillin; cephalosporins represented by cephalothin; aminoglycosides represented by gentamycin; tetracycline represented by tetracycline; phenicols represented by chloromphenicol; sulphonamides and trimethoprim represented by sulfamethoxate-trimethoprim; macrolides represented by erythromycin; glycopeptide represented by vancomycin (Oxoid).

\subsection{5. Genotypic detection of isolated} L. monocytogenes and some virulence genes:

PCR using five sets of primers (Table 1) was used for genotypic detection of $L$. monocytogenes strains and their virulence 
genes. These genes were 16SrRNA gene; internalin A (inlA); Positive regulatory factor ( $r f f$ ); Listeriolysin $\mathrm{O}$, haemolysin (hlyA) and Phospholipase A (plcA). It was applied on six random isolates of $L$. monocytogenes, following QIA amp® DNA
Mini Kit instructions (Catalogue no. M501DP100), Emerald Amp GTPCR master mix (Takara) with Code No. RR310A and $1.5 \%$ agarose gel electrophoreses (Sambrook et al., 1989).

Table (1): Oligonucleotide primers sequences

\begin{tabular}{|c|c|c|c|}
\hline Primer & Sequence & $\begin{array}{l}\text { Amplified } \\
\text { product }\end{array}$ & Reference \\
\hline $\begin{array}{l}6 S \\
r R N A\end{array}$ & $\begin{array}{l}\text { F- GGA CCG GGG CTA ATA CCG AAT GAT AA } \\
\text { R- TTC ATG TAG GCG AGT TGC AGC CTA }\end{array}$ & $1200 \mathrm{bp}$ & $\begin{array}{l}\text { Kumar et al., } \\
2015\end{array}$ \\
\hline prfa & $\begin{array}{l}\text { F- TCT-CCG-AGC-AAC-CTC-GGA-ACC } \\
\text { R- TGG-ATT-GAC-AAA-ATG-GAA-CA }\end{array}$ & 1052 bp & $\begin{array}{l}\text { Dickinson et } \\
\text { al., } 1995\end{array}$ \\
\hline inlA & $\begin{array}{l}\text { F- ACG AGT AAC GGG ACA AAT GC } \\
\text { R- CCC GAC AGT GGT GCT AGA TT }\end{array}$ & 800 bp & $\begin{array}{l}\text { Liu et al., } \\
2007\end{array}$ \\
\hline hlyA & $\begin{array}{l}\text { F- GCA-TCT-GCA-TTC-AAT-AAA-GA } \\
\text { R- TGT-CAC-TGC-ATC-TCC-GTG-GT }\end{array}$ & 174 bp & $\begin{array}{l}\text { Deneer and } \\
\text { Boychuk, } \\
1991\end{array}$ \\
\hline plcA & $\begin{array}{l}\text { F- ACA AGC TGC ACC TGT TGC AG } \\
\text { R- TGA CAG CGT GTG TAG TAG CA }\end{array}$ & 1484 bp & $\begin{array}{lll}\text { Soni et al., } \\
2014\end{array}$ \\
\hline
\end{tabular}

\section{RESULTS}

A total of $53(13.25 \%)$ isolates of Listeria monocytogenes were recovered from 400 samples includes 11(2.75\%) isolates from muscles, $21(5.25 \%)$ from liver, $8(2 \%)$ from spleen and $13(3.25 \%)$ from kidneys (Table 2).

The isolated colonies grow well and showed gray green colonies with black depressed button center and black hollow surrounded them on PALCAM agar, black colonies with dimpled centers on Oxford agar and green-blue colonies surrounded by an opaque halo on ALOA agar.

They were Gram - positive bacilli or coccobacilli; were motile at room temperature on Semisolid trypticase soy agar with yeast extract and showing the characteristics umbrella growth and the templing motility.

The Biochemical reactions showed that all strains were catalase (+); oxidase (-) and produce acid with dextrose, L-rhamnose but not with mannitol, D-xylose and sucrose.

The results of virulence tests proved that, all isolated $L$. monocytogenes strains were CAMP test positive with zone of $\beta$ hemolysis at the junction of tested strains and $S$. aureus strains. In addition, all of them produced purulent conjunctivitis within 24-48 hours followed by keratitis in all rabbits (Anton's test positive).

The results of antimicrobial sensitivity tests for the isolated L. monocytogenes 
Prevalence and molecular studies on Listeria monocytogenes isolated from chicken in El-Gharbia Governorate

(Table 3) showed that the isolated $L$. monocytogenes $(\mathrm{n}=12)$ were sensitive to sulfamethoxate-trimethoprim

$(91.6 \%)$

followed by ampicillin, gentamycin, vancomycin and chloromphenicol (83.3\%) followed by ciprofloxacin $(66.6 \%)$ followed by erythromycin and tetracycline $(50.0 \%)$, while the isolated strains were completely resistant to cephalothin.

The PCR results for L. monocytogenes showed that, all genes (16SrRNA; inlA; inlB; $h l y A$ and $\operatorname{prf} A$ ) were detected in all six studied strains $(100.0 \%)$ while plcA gene was not detected. i.e., all six studied strains were L. monocytogenes and were virulent strains.

The (16SrRNA; inlA; prfA; hlyA were amplified at 1200, 800, 1052, 174 bp respectively for the six isolates of $L$. monocytogenes (figures 1-4) but plcA gene was not detected (100\%) (Figure 5).

Table (2): Prevalence of Listeria monocytogenes isolated from different organs in chicken samples

\begin{tabular}{cccc}
\hline Samples & $\begin{array}{c}\text { Number of } \\
\text { samples }\end{array}$ & $\begin{array}{c}\text { Number of } \\
\text { positive samples }\end{array}$ & $\begin{array}{c}\text { Positive } \\
\text { percentage } \%\end{array}$ \\
\hline Muscles & 100 & 11 & 2.75 \\
Liver & 100 & 21 & 5.25 \\
Spleen & 100 & 8 & 2 \\
Kidneys & 100 & 13 & 3.25 \\
Total & 400 & 53 & 13.25 \\
\hline
\end{tabular}

Table (3): Results of antimicrobial sensitivity test for isolated Listeria monocytogenes strains $(\mathrm{n}=12)$

\begin{tabular}{|c|c|c|c|c|c|c|c|}
\hline \multirow{2}{*}{$\begin{array}{c}\text { Antimicrobial } \\
\text { Family }\end{array}$} & \multirow{2}{*}{$\begin{array}{l}\text { Antimicrobial } \\
\text { disc }\end{array}$} & \multicolumn{2}{|c|}{$\begin{array}{l}\text { Sensitive } \\
\text { Isolates }\end{array}$} & \multicolumn{2}{|c|}{$\begin{array}{l}\text { Intermediate } \\
\text { Isolates }\end{array}$} & \multicolumn{2}{|c|}{$\begin{array}{l}\text { Resistant } \\
\text { Isolates }\end{array}$} \\
\hline & & Number & $\%$ & Number & $\%$ & Number & $\%$ \\
\hline Fluoroquinolones & Ciprofloxacin(CIP) & 8 & 66.6 & 4 & 33.3 & 0 & 0 \\
\hline$\beta$-lactam & Ampicillin(AMP) & 10 & 83.3 & 1 & 8.3 & 1 & 8.3 \\
\hline Cephalosporins & Cephalothin(KF) & 0 & 0 & 0 & 0 & 12 & 100 \\
\hline Aminoglycosides & Gentamycin $(\mathrm{CN})$ & 10 & 83.3 & 1 & 8.3 & 1 & 8.3 \\
\hline Tetracycline & Tetracycline (TE) & 6 & 50 & 0 & 0 & 6 & 50 \\
\hline Phenicols & Chloromphenicol C)) & 10 & 83.3 & 0 & 0 & 2 & 16.6 \\
\hline $\begin{array}{l}\text { Sulphonamides } \\
\text { and trimethoprim }\end{array}$ & $\begin{array}{c}\text { Sulfamethoxate- } \\
\text { Trimethoprim SXT)) }\end{array}$ & 11 & 91.6 & 0 & & 1 & 8.3 \\
\hline Macrolides & Erythromycin $(\mathrm{E})$ & 6 & 50 & 2 & 16.6 & 4 & 33.3 \\
\hline Glycopeptide & Vancomycin (VA) & 10 & 83.3 & 1 & 8.3 & 1 & 8.3 \\
\hline
\end{tabular}




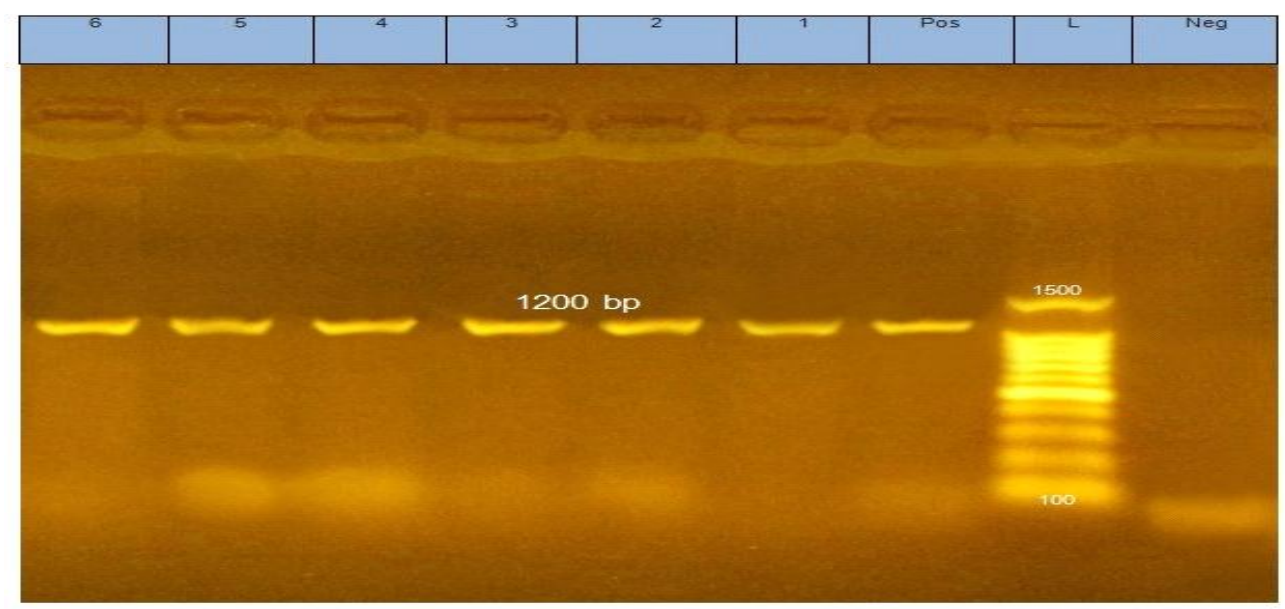

Figure (1): Agarose gel electrophoresis of 16SrRNA genes.

Lane L: 100-1500bp Ladder. Neg.: Negative control. Pos.: Positive control (at 1200bp). Lanes from 1 to 6: L. monocytogenes (16S rRNA) gene positive at $1200 \mathrm{bp}$.

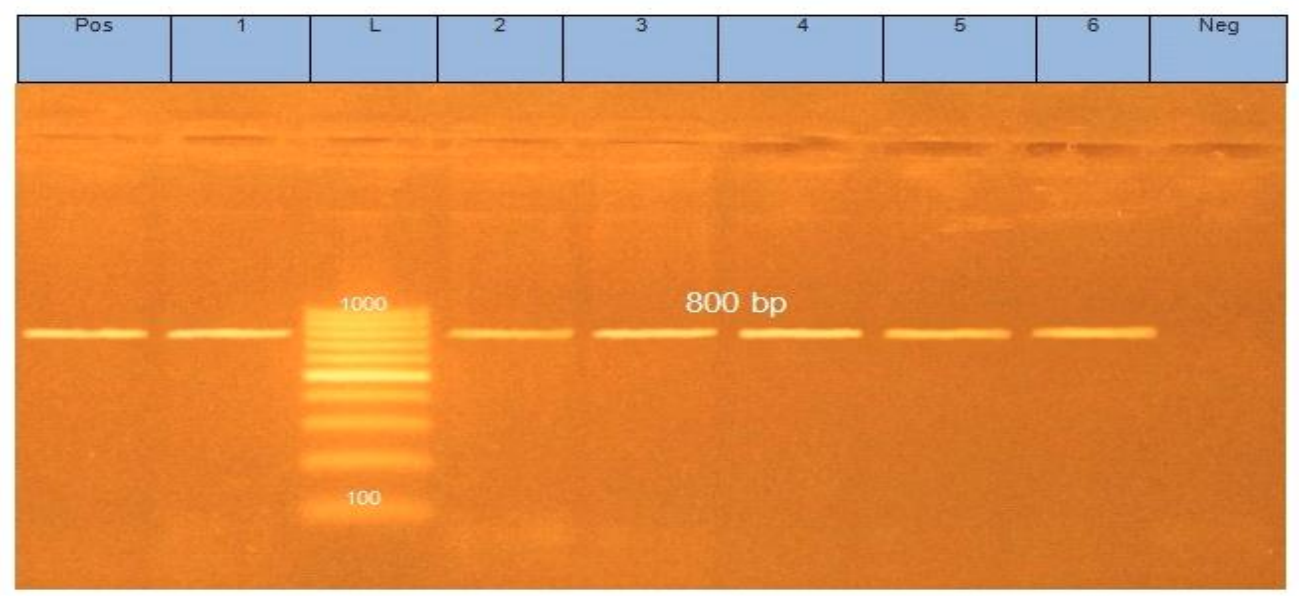

Figure (2): Agarose gel electrophoresis of internalin A (inlA) genes.

Lane L: 100-1000bp Ladder. Neg.: Negative control. Pos.: Positive control (at $800 \mathrm{bp}$ ). Lanes from 1 to 6: L. monocytogenes(inlA) gene positive at $800 \mathrm{bp}$. 
Prevalence and molecular studies on Listeria monocytogenes isolated from chicken in El-Gharbia Governorate

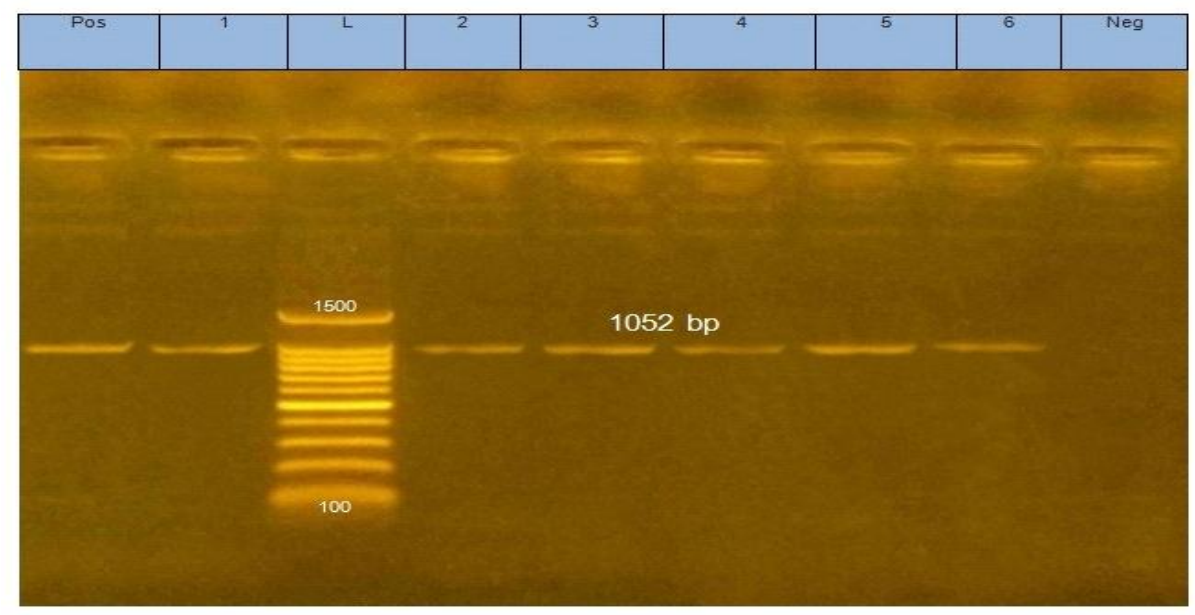

Figure (3): Agarose gel electrophoresis of Positive regulatory factor (prfA) genes. Lane L: 100-1500bp Ladder. Neg.: Negative control. Pos.: Positive control (at 1052bp). Lanes from 1 to $6: L$. monocytogenes (prfA) gene positive at 1052bp.

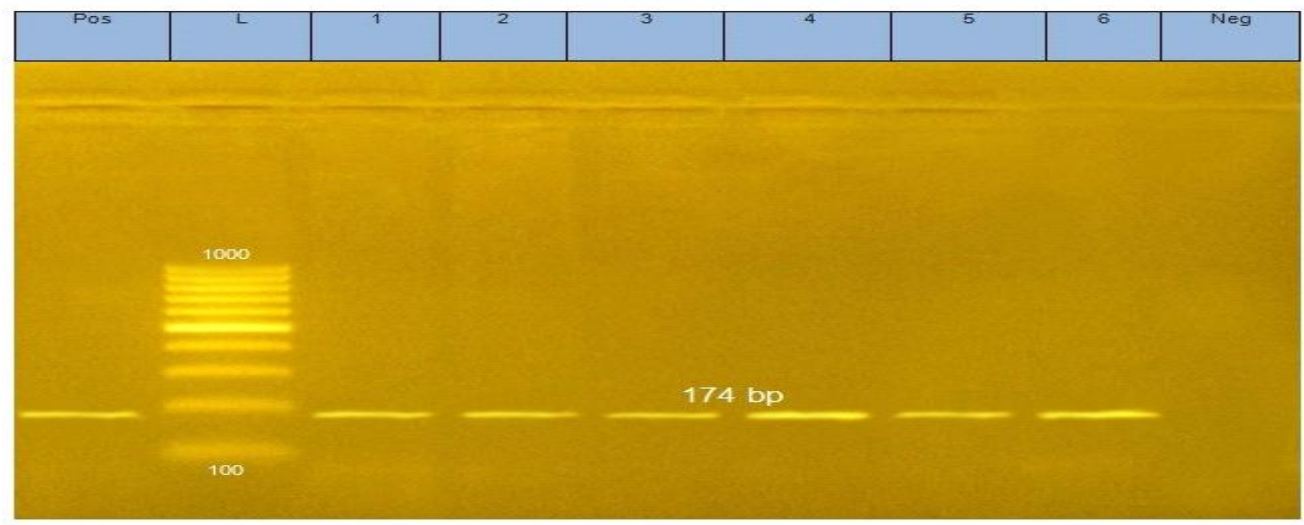

Figure (4): Agarose gel electrophoresis of Listeriolysin O, haemolysin (hylA) genes. Lane L: 100-1000 bp Ladder. Neg.: Negative control. Pos.: Positive control (at $174 \mathrm{bp}$ ). Lanes from 1 to 6: L. monocytogenes (hylA) gene positive at $174 \mathrm{bp}$. 


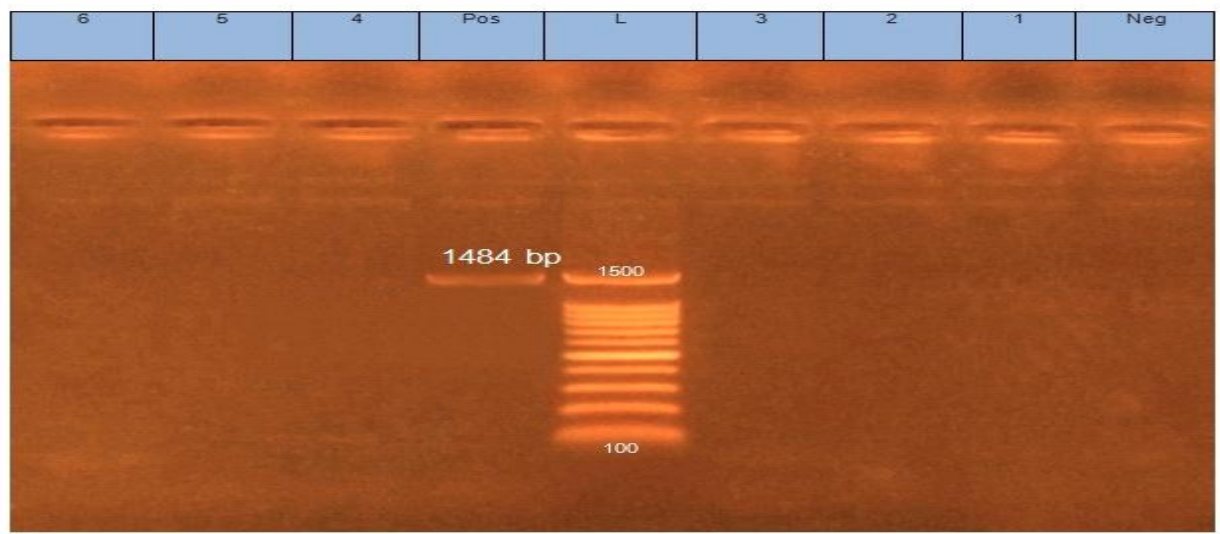

Figure (5): Agarose gel electrophoresis of Phospholipase A ( $p l c A$ ) genes. Lane L: 100-1500bp Ladder. Neg.: Negative control. Pos.: Positive control (at 1484bp). Lanes from 1 to 6: L. monocytogenes ( $p l c A)$ gene negative.

\section{DISCUSSION}

In the present study a total of 400 examined chicken samples, 53 isolates (13.25\%) of Listeria monocytogenes were isolated (Table 2). This is nearly similar to Osaili et al., (2011), Swetha et al., (2013), Saludes et al., (2015) and AL-Jobori et al., (2016) who isolated L. monocytogenes from chicken by (18\%), (16\%), (19\%) and (11\%) respectively.

These results in El-Gharbia Governorate $(13.25 \%)$ are higher than recorded by Ali and Shalaby (2002) in Giza city 3.3\%, Farghaly (2011) in Cairo Governorate $3.6 \%$ and Dahshan et al., (2016) in Sharkia Governorate in Egypt who did not detected L. monocytogenes from chicken samples.

However, higher prevalence rate of $L$. monocytogenes isolated from chicken were recorded by Minamia et al., (2010), Pesavento et al., (2010), Kuan et al., (2013) and Zeinali et al., (2017) who isolated $L$. monocytogenes from chicken by (36\%), (24.5\%), (26.39\%) and (18\%), respectively.

The colonial appearance of the recovered isolates in this study grow well and showed: small $2-3 \mathrm{~mm}$ in diameter; gray green colonies in color with black depressed button center and black hollow surrounded them (esculin hydrolysis) on PALCAM agar that was similar to the previously recorded studied by (Osman et al., (2014) and Abd El-Tawab et al., (2015). Black colonies with dimpled centers on Oxford agar that was similar to the previously recorded studied by (Magalhães et al., (2014) and Abd El-Tawab et al., (2015). Green-blue (due to presence of $\beta$ glucosidase) regular round colonies surround by an opaque halo (due to the activity of phospholipase involved in pathogenic Listeria) on ALOA agar that was similar to the previously recorded studied by (Jeyaletchumi et al., (2010a) and Abd El-Tawab et al., (2015).

The results of biochemical identification showed characteristic 
identical biochemical reaction to be Listeria species that was similar to the previously recorded studied by (Schmid et al., (2005); Todar, (2009) and Abd El-Tawab et al., (2015).

All isolated Listeria were motile at room temperature and showing the characteristics umbrella growth and the templing motility that was similar to the previously recorded studied by (Ryser and Marth, (2007); Bhunia, (2008); Todar, (2009) and Abd El-Tawab et al., (2015).

The result of virulence tests for the isolated Listeria monocytogenes strains appeared that, all L. monocytogenes strains were virulent strains, where all of them were positive to CAMP test and showed narrow zone of $\beta$-hemolysis on sheep blood agar. Also, all L. monocytogenes isolates were positive for Anton's test. That was similar to the previously recorded studied by (Maarouf et al., (2007); Todar, (2009); Fentahun and Fresebehat, (2012) and Abd El-Tawab et al., (2015).

The results of antimicrobial sensitivity tests for the isolated L. monocytogenes (Table 3) showed that the isolated $L$. monocytogenes were sensitive to Sulfamethoxate-Trimethoprim (91.6\%) followed by ampicillin, gentamycin, vancomycin and chloromphenicol (83.3\%) followed by ciprofloxacin $(66.6 \%)$ followed by erythromycin and tetracycline (50.0\%), while the isolated strains were completely resistant to cephalothin. Nearly similar results were recorded by Conter et al., (2009); Granier et al., (2011) and Altuntas et al., (2012).
The PCR technique can identify the pathogenic L. monocytogenes based on the fact that virulence varies not only among different species but also among strains of the same species. Thus, numerous studies have been conducted to identify virulence factors of isolated L. monocytogenes strains (Shen et al., 2013; Khan et al., 2014 and Ciolacu et al., 2015).

So, the present study was directed mainly to genotypic detection of $L$. monocytogenes strains and virulence genes that may play a role in virulence of $L$. monocytogenes by using one of the recent developments molecular biological techniques (PCR). These genes were 16 rRNA gene; internalin A (inlA); Positive regulatory factor ( $p r f A)$; Listeriolysin $\mathrm{O}$, haemolysin $(h l y A)$ and Phospholipase A (plcA).

The PCR results for six studied strains of L. monocytogenes isolates showed that, the genes (16rRNA, inlA, hlyA and prfA) were detected (100.0\%). i.e., all six studied strains were L. monocytogenes and all of them were virulent strains. Similar results were decided by Shen et al., (2013); Abd El-Tawab et al., (2015) and Ciolacu et al., (2015); as well as they reported that, PCR save time for diagnosis hence allowing a rapid identification of $L$. monocytogenes with high sensitivity and specificity.

While the result of PCR for amplification of Phospholipase A (plcA) gene in L. monocytogenes (Figure 5) showed that, it was not detected in all six studied strains of L. monocytogenes isolates in the current study. 
Finally, from results of the present work it could be concluded that, Listeria monocytogenes are serious pathogens could be contaminated chickens in El-Gharbia Governorates, Egypt.

\section{REFERENCES}

Abd El-Tawab, A.A.; Ahmed, A.A.M.; Zeinab, A.M., 2015. Bacteriological and Molecular studies of Listeria species in milk and milk products at El-Kaliobia Governorate. Benha Veterinary Medical Journal, Vol. 29 (2):170-181.

Akanbi, O.B.; Breithaupt, A.; Polster, U.; Alter, T.; Quandt, A.; Bracke, A.; Teifke, J.P., 2008. Systemic Listeriosis in caged canaries (Serinuscanarius). Avian Pathol., 37: 329-332.

Ali, F.H.M.; Shalaby, O.F.H.B., 2002. Incidence of Listeria and Yersisnis species among slaughtered poultry and rabbit with special reference to its zoonotic importance. Vet. Med. J. Giza, 50 (4):571-579.

AL-Jobori, K.M.; Hasan, M.L.M.; Nader, M.I., 2016. Detection of E. coli, Salmonella spp. and Listeria monocytogenes in Retail Chicken Meat and Chicken Giblets Samples Using Multiplex PCR in Baghdad City. Int. J. Curr. Microbiol. App. Sci, 5(9): 290301.

Altuntas, E.; Kocan, D.; Cosansu, S.; Ayhan, K.; Juneja, V.; Materon, L., 2012. Antibiotic and Bacteriocin sensitivity of L. monocytogenes strains isolated from different foods. Food and Nutrioin Sciences, 3(3): 363-368.
Bhunia, A.K., 2008. Food-borne Microbial Pathogens: Mechanisms and Pathogenesis. Springer, New York, ISBN-13: 9780387745367, pp: 165182.

Ciolacu, L.; Nicolau, A.I.; Wagner, M.; Rychli, K., 2015. Listeria monocytogenes isolated from food samples from a Romanian black market show distinct virulence profiles. Int. J. Food Microbiology, 209:44-51.

Clinical Laboratory Standards Institute (CLSI), 2014. Performance Standards for Antimicrobial Susceptibility Testing; twenty-fourth informational supplement. M100-S24.Clinical and Laboratory Standard Institute for antimicrobial susceptibility testing standards M100-S24, 34(1), 1-226.

Conter, M.; Paludi, D.; Zanardi, E.; Ghidini, S.; Vergara, A.; Ianieri, A., 2009. Characterization of antimicrobial resistance of foodborne Listeria monocytogenes. International Journal of Food Microbiology, 128, 497-500.

Dahshan, H.; Merwad, A.M.A.; Mohamed, T.S., 2016. Listeria Species in Broiler Poultry Farms: Potential Public Health Hazards. J. Microbiol. Biotechnol. 26(9), 1551-1556.

Deneer, H.G.; Boychuk, I., 1991. SpeciesSpecific Detection of Listeria monocytogenes by DNA Amplification. Applied and Environmental Microbiology, Feb. 1991, p. 606-609.

Dickinson, J.H.; Kroll, R.G.; Grant, K.A., 1995. The direct application of the 
Prevalence and molecular studies on Listeria monocytogenes isolated from chicken in El-Gharbia Governorate

polymerase chain reaction to DNA extracted from foods. Letters in Applied Microbiology 1995, 20, 212216.

Farghaly, T.I.T., 2011. Studies on Listeria infection in chickens. Master in Veterinary Mediccal Science (Bacteriology, Immunology and Mycology), Faculty of Veterinary Medicine Cairo University.

Fentahun, T.; Fresebehat, A., 2012. A review of Listeriosis in Small Ruminants. Advances in Biological Research, 6(6): 202-209.

Gouws, P.A.; Liedemann, I., 2005. Evaluation of Diagnostic PCR for the Detection of Listeria monocytogenes in Food Products. Food technol. Biotechnol., 43(2): 201-205.

Granier, S.A.; Moubareck, C.; Lemire, A.; Roussel, S.; Dao, T.T.; Courvalin, P.; Brisabois, A., 2011. Antimicrobial resistance of Listeria monocytogenes isolated from food and the environment in France over a 10-year period. Appl. Envir. Microbiol., (77): 2788-2790.

ISO, 2005. Microbiology of food and animal feeding stuffs-Horizontal method for the detection and enumeration of Listeria monocytogenes-part 1 : Detection method. International Standard ISO 11290-1. Amendment 1. Geneva. Switzerland.

Jacquet, C.; Gouin, E.; Jeannel, D.; Cossart, P.; Rocourt, J., 2002. Expression of ActA, Ami, InlB and listeriolysin $\mathrm{O}$ in Listeria monocytogenes of human and food origin. Applied and
Environmental Microbiology 68: 616622.

Jalali, M.; Abedi, D., 2007. Prevalence of Listeria species in food products in Isfahan, Iran. Int. J. Food Microbiol., 122: 336-340.

Jeyaletchumi, P.; Tunung, R.; Margaret, S.P.; Son, P.; Farinazleen, M.G.; Cheah, Y.K., 2010a. Detection of Listeria monocytogenes in foods. Int. Food Res. J. 17, 1-11.

Karthikeyan, R.; Gunasekaran, P.; Rajendhran, J. 2015. Molecular Serotyping and Pathogenic Potential of Listeria Monocytogenes Isolated from Milk and Milk Products in Tamil Nadu, India. Foodborne Pathog. Dis. 12(6) 522-8.

Khan, J.A.; Rathore, R.S.; Khan, S.; Ahmad, I., 2014. In vitro detection of pathogenic Listeria monocytogenes from food sources by conventional, molecular and cell culture method. Braz. J. Microbiol., 44(3): 751-759.

Kirkani, S.; Ergun, O.G.; Osman, K., 2005. Detection of Listeria monocytogenes by using PCR in helix pomatia. Turk. J. Vet. Anim. Sci.30 (2005) 375-380.

Kuan, C.H.; Goh, S.G.; Loo, Y.Y.; Chang, W.S.; Lye, Y.L.; Puspanadan, S.; Tang, J.Y.H.; Nakaguchi, Y.; Nishibuchi, M.; Mahyudin, N.A.; Radu, S. 2013. Prevalence and quantification of Listeria monocytogenes in chicken offal at the retail level in Malaysia. Poult. Sci., 92(6), 16641669. 
Kumar, A.; Grover, S.; Batish, V.K., 2015. Exploring specific primers targeted against different genes for a multiplex PCR for detection of Listeria monocytogenes. 3 Biotech (2015) 5:261-269.

Kurazono, M.; Nakamura, K.; Yamada, M.; Yonemaru, T.; Sakoda, T., 2003. Pathology of Listerial encephalitis in chickens in Japan. Avian Dis., 47(4): 1496 - 1502.

Liu, D.; Lawrence, M.L.; Austin, F.W.; Ainsworth, A.J., 2007. A Multiplex PCR for species and virulence-specific determination of Listeria monocytogenes. Journal of Microbiology Methods (71): 133-140.

Maarouf, A.A.; El-Bealawy, M.A.; Moubarak, M.G., 2007. Some studies of Listeriosis in sheep at Kaliobia governate. J. Egypt. Vet. Med. Assoc. 67(4): 27-40.

Mackiw, E.; Modzelewska, M.; Maka, L.; Sciezynska, H.; Pawlowska, K.; Postupolski, J.; Korsak, D., 2016. "Antimicrobial resistance profiles of Listeria monocytogenes isolated from ready to eat product in Poland in 20072011. Food Control, 59: 7-11.

Magalhães, R.; Mena, C.; Ferreira, V.; Almeida, G.; Silva, J.; Teixeira, P., 2014. Traditional methods for isolation of Listeria monocytogenes, in Listeria monocytogenes: Methods and Protocols, eds K. Jordan, E.M. Fox, and M. Wagner (New York, NY: Springer Science), 15-30.
Markey, B.K.; Leonard, F.C.; Archambault, M.; Cullinane, A.; Maguire, D., 2013. Clinical Veterinary Microbiology. Second edition. MOSBY. Elsevier Ltd. Edinburgh London New York Oxford Philadelphia St Louis Sydney Toronto.

Mckellar, R.C., 1994. Use of the CAMP test for identification of Listeria monocytogenes. Appl. Environ. Microbiol., 60 (12): 4219-4225.

Minamia, A.; Chaicumpab, W.; ChongsaNguanc, M.; Samosornsukd, S.; Monden, S.; Takeshi, K.; Makino, S.; Kawamoto, K., 2010. Prevalence of foodborne pathogens in open markets and supermarkets in Thailand. Food Control., 21(3): 221-226.

Orsi, R.H.; Wiedmann, M., 2016. Characteristics and distribution of Listeria spp., including Listeria species newly described since 2009. Applied Microbial Biotechnology, pp. 52735287.

Osaili, T.M.; Alaboudi, A.R.; Nesiar, E.A., 2011. "Prevalence of Listeriaspp. and antibiotic susceptibility of Listeria monocytogenes isolated from raw chicken and ready-to-eat chicken products in Jordan. Food Control, 22 (3-4): 586-590.

Osman, K.M.; Samir, A.; Orabi, A.; Zolnikov, T.R., 2014. Confirmed low prevalence of Listeria monocytogenes in she-camel milk delivers a safe, alternative milk for human consumption. Acta Trop. 130, 1-6.

Pesavento, G.; Ducci, B.; Nieri, D.; Comodo, N.; Lo Nostro, A., 2010. 


\section{Prevalence and molecular studies on Listeria monocytogenes}

isolated from chicken in El-Gharbia Governorate

"Prevalence and antibiotic susceptibility of Listeria spp. isolated from raw meat and retail foods. Food Control 21, 708-713.

Quinn, P.J.; Markey, B.K.; Carter, M.E.; Donnelly, W.J.C.; Leonard, F.C.; Maguire, D., 2002. Veterinary microbiology and microbial disease. Iowa State Univ. Press, Blackwell Science Ltd, 84-96.

Quinn, P.J; Markey, B.K.; Leonard, F.C.; Hartigan, P.; Fanning, S.; Fitz Patrick, E., 2011. Veterinary microbiology and microbial disease, John Wiley and Sons.

Ryser, E.T.; Marth E.H. 2007. Listeria, Listeriosis and Food Safety. Taylor and Francis; Boca Raton, FL: 2007.

Saludes, M.; Troncoso, M.; Figueroa, G. 2015. Presence of Listeria monocytogenes in Chilean food matrices. Food Control, 50, 331335 .

Sambrook, J., Fritsch, E.F.; Maniatis, T.; 1989. Molecular cloning. A laboratory manual. Vol. 1, Cold spring Harbor Laboratotry press, New York. 3 pages.

Schmid, M.W.; Ng, E.Y.; Lampidis, R.; Emmerth, M.; Walcher, M.; Kreft, J.; Goebel, W.; Wagner, M.; Schleifer, K.H., 2005. Evolutionary history of the genus Listeria and its virulence genes. Syst. Appl. Microbiol., 28(1), 118.
Scortti, M.; Monzó, H.J.; Lacharme-Lora, L.; Lewis, D.A.; Vázquez-Boland, J.A., 2007. The PrfA virulence regulon. Microbes Infect.; 9(10):1196207.

Shen, J.; Rump, L.; Zhang, Y.; Chen, Y.; Wang, X.; Meng, J., 2013. Molecular subtyping and virulence genes analysis of Listeria monocytogenes isolates from food. Food Microbiology, (35): 58-64.

Soni, D.K.; Singh, M.; Singh, D.V.; Dubey, S.K., 2014. Virulence and genotypic characterization of Listeria monocytogenes isolated from vegetable and soil samples. BMC Microbiology, 14:241.

Swetha, C.S., Madhava Rao, T.; Krishnalah, N., 2013. Detection of Listeria monocytogenes in chicken, pork and fish by PCR technique. ISOPOL XVIII: 116.

Todar, K., 2009. "Listeria monocytogenes". Todar's Online Textbook of Bacteriology. http://textbookofbacteriology.net/Lister ia.html.

Zeinali, T.; Jamshidi, A.; Bassami, M.; Rad, M., 2017. Isolation and identification of Listeria spp. in chicken carcasses marketed in northeast of Iran. International Food Research Journal 24(2): 881-887. 